\title{
Rask invasiv behandling av hjerteinfarkt
}

\author{
Rask invasiv behandling av hjerteinfarkt uten ST-heving gir økt overlevelse, \\ viser en skandinavisk multisenterstudie.
}

I en randomisert multisenterstudie ved 58 sykehus i Sverige, Danmark og Norge ble pasienter med akutt hjerteinfarkt uten STheving fulgt i 15 år. Tiden til nytt hjerteinfarkt eller død var lengre hos pasienter som fikk invasiv behandling enn hos dem som

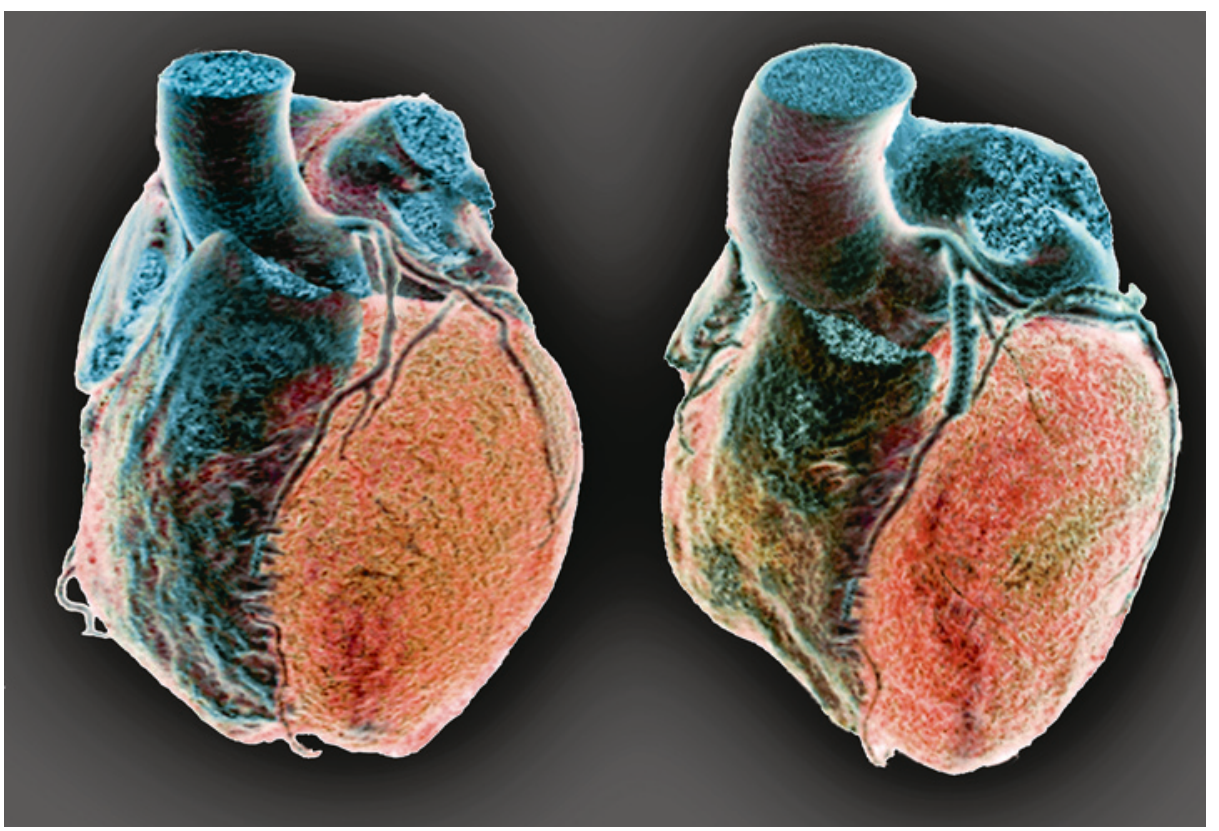

Perkutan koronar intervensjon. Foto: Science Photo Library

\section{Proteinstrukturen til ATP-syntase kartlagt}

\author{
Den komplette strukturen til ATP- \\ syntasen viser det molekylære \\ grunnlaget for mitokondrienes \\ morfologi.
}

ATP-syntasene er lokalisert i mitokondriens indre membran. Disse små molekylære maskinene produserer ATP i cellen og er viktige i utviklingen av nevrodegenerative sykdommer. Kjennskap til proteinets tredimensjonale struktur kan gi informasjon om proteinets mekanismer. I en ny studie ble ATPsyntase fra gjær, Yarrowia lipolytica, renset på en affinitetskolonne. Deretter ble strukturen kartlagt med en kombinasjon av kryo(1). 58 av 60 subenheter i ATP-syntasens dimerkompleks ble kartlagt, der man viste elektronmikroskopi og røntgendiffraksjon bare mottok medikamentell behandling, 1128 mot 579 dager $(p=0,002)$. Studien er nylig publisert i tidsskriftet The Lancet (1).

Ved den invasive tilnærmingen var målet revaskularisering innen syv dager fra symptomdebut, enten ved hjelp av perkutan inter- vensjon eller koronarkirurgi. Effekten var særlig stor hos ikke-røykere og hos pasienter med økte nivåer av troponin $\mathrm{T}$ og vekst- og differensieringsfaktor 15 (GDF 15).

Revaskulering ble foretatt innen syv dager hos $75 \%$ av pasientene som ble randomisert til invasiv behandling. Om lag 14\% av pasientene som ble randomisert til ikkeinvasiv behandling, fikk likevel revaskulering behandling under innleggelsen. Koronarangiografi ble foretatt ved refraktære eller tilbakevendende symptomer på tross av optimal ikke-invasiv behandling, eller der en belastningstest viste tegn til utbredt iskemi. Etter den første innleggelsen fikk $49 \%$ av pasientene som hadde fått ikke-invasiv behandling, revaskuleringsbehandling mot $24 \%$ av dem som hadde fått invasiv behandling.

- Denne studien med 15 års oppfølging styrker allerede eksisterende data som viser at tidlig invasiv behandlingsstrategi både reduserer og utsetter død, hjerteinfarkt og innleggelser med ustabilt koronarsyndrom, sier overlege Bjørn Bendz ved Hjertemedisinsk avdeling, Oslo universitetssykehus.

\section{Petter Morten Pettersen}

Tidsskriftet

\section{Litteratur}

1. Wallentin L, Lindhagen L, Ärnström E et al; FRISCII study group. Early invasive versus non-invasive treatment in patients with non-ST-elevation acute coronary syndrome (FRISC-II): 15 year follow-up of a prospective, randomised, multicentre study. Lancet 2016; 388: 1903-11. hvordan rotorkatalyse genererer ATP og hvordan dimerstrukturen påvirker morfologien til mitokondriens indre membran.

- Siden den første tredimensjonale strukturen av myoglobin ble publisert i 1958, er mer enn 125000 proteinstrukturer fra ulike organismer blitt løst og deponert i strukturdatabasen PDB, sier forsker Bjørn Dalhus ved Avdeling for medisinsk biokjemi, Universitetet i Oslo og Oslo universitetssykehus. - Av disse er kun rundt 2,5\% membranproteiner, noe som reflekterer hvor vanskelig det er å arbeide med isolering og krystallisering av membranproteiner. Mange proteiner er komponenter i større komplekser, noe som gjør det ekstra vanskelig.

- I denne studien har man klart å bestemme en nesten komplett struktur til en ATP-syntase fra gjær ved å kombinere to teknikker, nemlig kryoelektronmikroskopi og røntgendiffraksjon. Den publiserte strukturen utgjør den til nå nærmeste analoge strukturen av human ATP-syntase. En slik modell gir verdifull informasjon om funksjon, molekylær virkningsmekanisme, interaksjon og samspill med andre cellulære komponenter, og ikke minst hvordan enkelte kritiske mutasjoner og defekter i proteiner kan gi patologiske fenotyper. Slike modeller kan være viktige verktøy i design av legemidler, sier Dalhus.

\section{Ruth Halsne \\ Tidsskriftet}

Litteratur

1. Hahn A, Parey K, Bublitz M et al. Structure of a complete ATP Synthase dimer reveals the molecular basis of inner mitochondrial membrane morphology. Mol Cell 2016; 63: 445-56. 